\title{
Angiotensin-converting enzyme gene: application possibilities in medicine and sports cardiology (literature review)
}

\author{
S. M. Malakhova \\ Zaporizhzhia State Medical University, Ukraine
}

Key words:

angiotensinconverting enzyme gene, genetic polymorphism, sports medicine.

Zaporozhye medical journal 2018; 20 (1), 128-132 DOI: 10.14739/2310-1210 2018.1.122155

E-mail: malakhova_sn@ukr.net
Aim. Formation of modern ideas about the effect of angiotensin-converting enzyme polymorphism on the functioning of various body systems including in athletes.

Methods of research. Analysis and synthesis of the modern scientific literature data.

Results. According to modern ideas of sport molecular genetics, individual differences in the expression degree of certain physical and mental qualities of a person are largely determined by DNA-polymorphisms. Specific features of angiotensin converting enzyme I/D gene polymorphism influence on life-supporting systems functioning of human, who do not engage in sports, have been revealed. This polymorphism is widely covered by professional athletes from the point of view of physical qualities development possibility, but at the same time, the risk of pathological conditions development, taking into account regular intensive physical exertion, has not sufficiently studied. Knowledge of the innate personal physical abilities will help to predict the strengths and weaknesses of a person's physical and adaptive capabilities and, accordingly, to make a timely correct prognosis for personal sports prospects and carry out competent selection of athletes. This approach will allow them to progress quickly and achieve high results in sport.

Conclusions. A feature of genetic markers that do not change throughout life is the possibility of their determination immediately after child's birth, thus, the prognosis for indicators development that are significant in the conditions of sport activities can be made much earlier. In the available to us literature, ACE I/D gene polymorphism is primarily evaluated from the perspective of speed-strength development of physical qualities, but at the same time, genetic testing of beginner athletes should allow us to identify a risk group relatively to a number of pathological conditions progression that are genetically determined. Thus, despite numerous studies that allow an assessment of ACE gene polymorphism contribution to the life-supporting organs and systems state, the role of the ACE gene remains being insufficiently studied in sports medicine.

\section{Ключові слова:} ген ангіотензинперетворювального ферменту, поліморфізм, спортивна кардіологія.

Запорізький медичний журнал. - 2018. T. 20, № 1(106). C. $128-132$

\section{Ген ангіотензинперетворювального ферменту: можиивості застосування в медицині та спортивній кардіології}

\section{С. М. Малахова}

Мета роботи - формування сучасних уявлень про вплив поліморфізму гена ангіотензинперетворювального ферменту на функціонування різних систем організму, в тому числі у спортсменів.

Матеріали та методи. Аналіз та узагальнення даних сучасної наукової літератури.

Результати. Відповідно до сучасних уявлень молекулярної генетики спорту, індивідуальні відмінності у ступені вираженості тих чи інших фрізичних і психічних якостей людини багато в чому зумовлені ДНК-поліморфізмами. Виявлено особливості впливу I/D поліморфрізму гена ангіотензинперетворювального ферменту на функціонування життєзабезпечувальних систем в осіб, які не займаються спортом. Цей поліморфізм доволі широко розкритий у професійних спортсменів із погляду можливості розвитку фізичних якостей, водночас недостатньо вивчені питання ризику розвитку патологічних станів з урахуванням регулярних інтенсивних фізичних навантажень. Знання вроджених фізичних здібностей допоможе прогнозувати сильні та слабкі сторони фрізичних та адаптаційних можливостей людини та, відповідно, робити своєчасний і правильний прогноз спортивної перспективності й здійснювати грамотну селекцію спортсменів. Такий підхід дасть можливість їм швидко прогресувати та досягати високих результатів у спорті.

Висновки. Особливістю генетичних маркерів, не змінних протягом усього життя, є можливість їх визначення відразу після народження дитини, отже, прогноз розвитку показників, які є значущими в умовах спортивної діяльності, можна складати набагато раніше. У доступній нам науковій літературі переважно оцінюється I/D поліморфізм гена ACE з погляду перспективи розвитку швидкісно-силових фізичних якостей, але водночас генетичне тестування спортсменів повинно дати можливість виявити групу ризику щодо прогресування низки патологічних станів, генетично детермінованих. Отже, попри численні дослідження, що дають змогу оцінити вплив поліморфізму гена АCE на стан життєзабезпечувальних органів і систем, роль гена АСЕ залишається недостатньо вивченою у спортивній медицині.

\section{Ключевые слова:} ген ангиотензинпревращающего фермента, полиморфизм, спортивная кардиология.

\section{Ген ангиотензинпревращающего фермента: возможности применения в медицине и спортивной кардиологии}

\section{С. Н. Малахова}

Цель работы - формирование современных представлений о влиянии полиморфизма гена ангиотензинпревращающего фермента на функционирование различных систем организма, в том числе у спортсменов. 
Материалы и методы. Анализ и обобщение данных современной научной литературы.

Запорожский медицинский журнал. - 2018. T. 20, № 1(106). соглласно современным представлениям молекулярной генетики спорта, индивидуальные разли степени выраженности тех или иных физических и психических качеств человека во многом обусловлены ДНК-полиморфизмами. Выявлены особенности влияния I/D полиморфизма гена ангиотензинпревращающего фермента на функционирование жизнеобеспечивающих систем у лиц, не занимающихся спортом. Данный полиморфизм достаточно широко освещен у профессиональных спортсменов с точки зрения возможности развития физических качеств, в то же время недостаточно изучены вопросы риска развития патологических состояний с учетом регулярных интенсивных физических нагрузок. Знание врожденных физических способностей человека поможет прогнозировать сильные и слабые стороны физических и адаптационных возможностей человека и, соответственно, делать своевременный и верный прогноз спортивной перспективности и осуществлять грамотную селекцию спортсменов. Такой подход позволит им быстро прогрессировать и достигать высоких результатов в спорте.

Выводы. Особенностью генетических маркеров, не меняющихся на протяжении всей жизни, является возможность их определения сразу после рождения ребенка, таким образом, прогноз развития показателей, значимых в условиях спортивной деятельности, можно составлять намного раньше. В доступной нам научной литературе преимущественно оценивается I/D полиморфизм гена ACE с точки зрения перспективы развития скоростно-силовых физических качеств, но в то же время генетическое тестирование начинающих спортсменов должно позволить выявить группу риска относительно прогрессирования ряда патологических состояний, генетически детерминированных. Таким образом, несмотря на многочисленные исследования, позволяющие оценить влияние полиморфизма гена АСЕ на состояние жизнеобеспечивающих органов и систем, роль гена АСЕ остается недостаточно изученной в спортивной медицине.

The actual problem of the modern training system of highly qualified athletes is the improvement of sport selection and sport orientation [13]. Modern professional sport makes the highest demands on the locomotor and functional characteristics of athletes. Nowadays, high-level sport is characterized by extremely intense and prolonged physical and neuropsychological loads, the range of which is limited by the genetic and physiological capabilities of the human body [15]. In connection of this, the issue of training process efficiency rising is thrown into sharp relief, as well as its aspects optimization, reserve capabilities determination and an athlete's body adaptive potential extension. It is obvious that the solution of this problem requires the principle of individualization at the early stages of sport trainings approach [3].

Individual features in the degree of adaptive changes in response to training incentives are largely determined by genetic factors that specify hereditary predisposition to the physical exertion tolerance. Knowledge of the innate personal physical abilities will help to predict the strengths and weaknesses of a person's physical and adaptive capabilities and, accordingly, to make a timely correct prognosis for personal sports prospects and carry out competent selection of athletes. This approach will allow them to progress quickly and achieve high results in sport [28].

It is known that personal physical qualities development and manifestation depend on both hereditary and surrounding factors. The human body undergoes definite morphofunctional and physiological changes under the influence of regular intense physical activity in the course of sport activity aimed to extend the range of functional capabilities and increase stress resistance [1]. The severity of these changes is determined by age and gender characteristics of individuals and to a greater extent by the peculiarities of their constitution.

Nowadays, there is a rapid development of sport molecular genetics in the arsenal of which highly effective technologies and methods have appeared that provide the ability to determine the molecular mechanisms of human physical qualities inheritance [4]. According to modern ideas of sport molecular genetics, individual differences in the degree of person's certain physical and mental qualities expression are largely determined by DNA-polymorphisms
[27]. Among the polymorphisms of the human genome, which are currently at least 13 million, the most common are single nucleotide polymorphisms of SNP, that is, single nucleotide positions in genomic DNA for which the population has different variants of sequences (alleles) [7].

Prediction of aerobic and anaerobic physical capacities of beginner athletes is possible only as a result of certain characteristics range complex assessment. In order to increase the effectiveness of such prognosis, it becomes necessary to create a diagnostic complex that includes the entire range of biochemical, physiological, and anthropometric methods, as well as a full-genome screening of loci associated with various physical qualities development and manifestation.

As a result of numerous studies in the field of physical genetics activity, more than 50 DNA loci linked to aerobic and anaerobic energy systems have been identified [14]. It should be noted that not a single endophenotype, but a complex of characteristics which determine any final phenotype, has been chosen as an object of this kind research. The application of this approach proceeds from the notion of synanthropic traits (interrelated signs that determine the final phenotype) and synanthropic genes.

\section{The aim}

The aim of the study - formation of modern ideas about the effect of angiotensin-converting enzyme polymorphism on the functioning of various body systems including in athletes.

\section{Methods of research}

Analysis and synthesis of modern scientific literature data.

\section{Results and discussion}

A classic example of a specific gene association variation with a complex of synanthropic features, which is based on the gene pleiotropy phenomenon, is the angiotensin converting enzyme (ACE) I/D gene polymorphism. The 
angiotensin-converting enzyme hydrolyses angiotensin-I decapeptide into the angiotensin II vasopressor, plays a key role in renin-angiotensin system (RAAS) activity regulation, which is responsible for blood vessels tone control, water-salt homeostasis maintaining, nourishing and stimulation of vessels and myocardium smooth muscle cells proliferation, and also affects fibrinolysis, platelets activation and aggregation [2].

The ACE gene produces 2 isoforms: 1) endothelial or somatic form which is expressed in many tissues, including vascular endothelial cells, renal epithelial cells, Leydig cells, duodenum, lungs, pulmonary blood vessels, prostate and 2) testicular form that is expressed only in sperm [21].

The ACE gene is characterized by insertion-deletion (I/D) polymorphism in the $16^{\text {th }}$ intron of chromosome 17q23. The fragment with length of 300 nucleotide pairs (n. p.) presence or absence is considered to be a marker for angiotensin converting enzyme gene polymorphism, the fragment 490 n. p. is typical for insertion (I), and 190 n. p. for the deletion (D). In accordance with the insertion/deletion of a given DNA fragment in the homo- or heterozygous state, the following genotypes are identified: II - homozygous for the presence of insertion; DD - homozygous for deletion; ID - heterozygous [24].

The association of the polymorphic insert of Alu-repeat (I/D polymorphism) in the $16^{\text {th }}$ intron of the ACE gene with the level of angiotensin-converting enzyme in plasma was revealed. This polymorphism determines about $47 \%$ of the variability of the ACE level in plasma and is associated with manifestations of essential hypertension, hypertrophic cardiomyopathy and ischemic heart disease [8]. Persons with a D/D genotype (the genotype was observed approximately in $36 \%$ of people), have the maximum ACE blood level, with I/I genotype (about $17 \%$ of people) - ACE blood level is less by half and heterozygote have intermediate blood enzyme level [9].

The ACE gene polymorphism has a significant effect on cardiovascular system diseases development and progression. Biochemical manifestations of the DD genotype are: increase in ACE level and activity and angiotensin II level, decrease in bradykinin level and sensitivity to sodium, insulin resistance. The phenotypic manifestations of this genotype include: hypertension, left ventricular (LV) myocardial hypertrophy, coronary artery spasm, myocardial infarction, more frequent development and severe kidney diseases, high risk of sudden death. In addition, in the presence of genotype D/D, smoking increases the risk of myocardial infarction by a factor of two. The presence of variant $D$ in both homozygous and heterozygous forms corresponds approximately to a twofold increase of fatal myocardial infarction risk. High levels of arterial pressure in $\mathrm{D} / \mathrm{D}$ genotype carriers cause the progression of hypertensive disease, initiating hypertrophic changes in the LV. Allele I and genotype II, in contrast, are factors that protect against hypertension development [10].

It is known that $I / D$ polymorphism significantly affects the progression of glomerular and tubulointerstitial kidney diseases. DD homozygotes have a higher concentration of angiotensin II receptors, which contributes to the progression of not only systemic, but also intrarenal hypertension. There is a number of conflicting data on DD polymorphism role in renal failure progression, which is probably related to ethnic characteristics [11]. The prevalence of DD genotype was revealed in patients with hereditary kidney pathology (glomerulonephritis, polycystosis), while the course of the disease is accompanied by a decrease in the glomerular filtration rate [6].

It was determined that if patients have type 2 diabetes, then the heterozygotes for ACE gene ID polymorphism reach compensation and subcompensation in diabetes treatment more often than in homozygotes carrying genotypes II and DD, the risk of patients' microvascular complications with the ID genotype is lower than of those patients with genotypes II and DD [12].

Numerous studies results favour for interaction of ACE gene I/D polymorphism with high sport achievements [16].

The ACE I allele prevails in the group of long-distance runners compared to the sprinters and control group [25], which is in complete conforms the data on the association of this allele with high values of maximum oxygen consumption (MOC) [23], the prevalence of slow muscle fibers in $\mathrm{m}$. vastus lateralis [22], as well as a reduced risk of myocardial hypertrophy development (a factor limiting cardiorespiratory endurance) in response to physical exertion [26].

Much attention is paid to the study of muscular activity influence on the physiological parameters of the organism in connection with ACE various allelic variants [17]. A high correlation between increased left ventricular mass after endurance training with the ACE elevated level in the blood and a D/D genotype was established. During the strength training of the quadriceps femur, the association of its strength with the ACE gene D allele was determined. Later these data were confirmed by measuring the isometric and isokinetic strength of this muscle in the D/D genotype carriers. The observed effect, apparently, depended on the different ratio of fast and slow muscle fibers. Individuals, who have the D/D genotype, the ratio of slow fibers to fast fibers was approximately the same, while slow fibers were predominant in $\mathrm{I} / \mathrm{I}$ individuals [18].

There is data on the frequency of athletes' ACE gene genotypes distribution in different kinds of sport. The D/D genotype predominates (31\%) among sportsmen who specialize in speed-power kinds of sport. Its frequency is reduced to $24 \%$ for sports requiring endurance and for athletes of the mixed group to $17 \%$. Thus, athletes with ACE gene $D / D$ genotype are more predisposed to speed-strength physical qualities development and persons with genotype I/I - to perform long-term physical work [19].

Certain studies cover the role of ACE gene in sports cardiology. Thus, athletes who keep up regular training program mostly aerobic kinds of sport (long distance running, skiing, cycling) have mainly increased the left ventricular cavity with a proportional increase in its walls thickness. This is caused by the increased cardiac output during exercising, i.e. reloading the volume of the left ventricle, as well as increasing systemic blood pressure. Left ventricle eccentric hypertrophy develops without changing the ratio of left ventricle wall thickness to its diameter [20]. Athletes with static or isometric trainings (weightlifting, martial artists and thrower hurlers) develop concentric hypertrophy with an increase in left ventricle wall thickness without its cavity size change, which is caused by afterload on the heart increase due to an increase in systemic arterial pressure during physical exercises [29]. 
According to echocardioscopy, athletes have an increase in left ventricle posterior wall and interventricular septum thickness by approximately 15-20\% compared to untrained people. The diastolic size of the left ventricle in most athletes is approximately $10 \%$ greater than that in untrained people, but it is within the reference values [5].

At the same time, according to Drozdovskaia S. (2014), the heart echocardiographic parameters of athletes who specialize in speed-power athletics do not statistically differ significantly from the average population. Most athletes have no signs of pathological cardiac remodeling. It is established that ACE gene D/D genotype contributes to more adequate adaptation to the speed-strength work in athletics.

\section{Conclusions}

Thus, despite numerous studies that allow an assessment of ACE gene polymorphism contribution to the life-supporting organs and systems state, the role of the ACE gene remains being insufficiently studied in sports medicine.

In the available to us literature, ACE I/D gene polymorphism is primarily evaluated from the perspective of speedstrength development of physical qualities, but at the same time, genetic testing of beginner athletes should allow us to identify a risk group relatively to a number of pathological conditions progression that are genetically determined.

It is important to note that the most accurate definition of a predisposition to sports should be made on the basis of significant number of markers analysis including phenotypic (anthropometry, functional diagnostics), as only by this way the environmental influence on genetically fixed signs can be reflected. At the same time, it is possible to evaluate the degree to a particular sport predisposition, indicating possible chances of achieving high results and risks of adverse cardiovascular events development. A feature of genetic markers that do not change throughout life is the possibility of their determination immediately after child's birth, thus, the prognosis for indicators development that are significant in the conditions of sport activities can be made much earlier.

The perspective of further research is further study of various angiotensin-converting enzyme gene polymorphisms effects on life-supporting organs and systems functions in highly skilled athletes with the aim to develop an algorithm for athletic performance prediction in the early stages of certain physical qualities development.

\section{References}

[1] Bondareva, E. A., \& Negasheva, M. A. (2017). Geneticheskie aspekty izucheniya sportivnoj uspeshnosti i sportivnogo otbora [Genetic Aspects of Athletic Performance and Sports Selection]. Uspekhi sovremennoj biologii, 137(1), 44-55. [in Russian].

[2] Dautova, A. Z., Usmanova, S. R., \& Shamratova, V. G. (2015). Vzaimosvyaz' polimorfizma gena ASE s sostoyaniem gazotransportnoj sistemy u lic s raznym urovnem dvigatel'noj aktivnosti [Correlation between polymorphism of the ACE gene with the state of gas-transportion system in persons with different level of motor activity]. Sovremennye problemy nauki i obrazovaniya, 3, 562. [in Russian].

[3] Drozdovskà, S. B. (2015). Kompleksna molekuliarno-henetychna diahnostyka fizychnoi pratsezdatnosti u sporti [Complex Molecular-Gene tic Diagnostics of Physical Performance in Sports]. Visnyk problem biolohii i medytsyny, 3(2), 332-338. [in Ukrainian].
[4] Drozdovska, S., Bobrovnik, V., Krivoruchenko, O., \& Ilyin, V. (2013) Polimorfizmy heniv, shcho spryiaiut vysokii fizychnii pratsezdatnosti u shvydkisno-sylovykh vydakh lehkoi atletyky [Gene polymorphisms that contribute to physical performance in high-speed and power kinds of track and field athletics]. Slobozhanskyi naukovo-sportyvnyi visnyk, 2, 49-54. [in Ukrainian].

[5] Drozdovska, S. B., \& Pastukhova, V. A. (2014). Ultrazvukove doslidzhennia sertsia sportsmeniv, yaki spetsializuiutsia u shvydkisno-sylovykh vydakh lehkoi atletyky z riznymy henotypamy za I/D polimorfizmom henu anhiotenzynperetvoriuiuchoho fermentu (ASE) [An ultrasound of the heart of athletes who specialize in speedstrength kinds of athletics with different genotypes for the I/D polymorphism of angiotensin converting enzyme gene (ACE)]. Ukrainskyi morfolohichnyi almanakh, 2, 13-16. [in Ukrainian].

[6] Kolesnikova, L. I., Dolgikh, V. V., \& Belyaeva, E. V. (2012). Rol' polimorfizma gena angiotenzinprevrashchayushchego fermenta $v$ realizacii arterial'noj gipertenzii u detej s glomerulonefritom [Role of angiotensin-converting enzyme gene polymorphism in the realization of arterial hypertension in children with glomerulonephritis]. Sibirskij medicinskij zhurnal, 1, 34-37. [in Russian].

[7] Kucher, A. N., Babushkina, N. P., Buikin, S. V., \& Puzyrev, V. P (2013). Plejotropnyye e'ffekty genov predraspolozhennosti mnogofaktornym zabolevaniyam [Pleiotropic effects of multifactorial disease susceptibility genes]. Molekulyarnaya medicina, 2, 13-23. [in Russian].

[8] Kucher, A. N., Buykin, S. V., Babushkina, N. P., Puzyrev, K. V., Garganeeva, A. A., Shipulin, V. M., \& Puzyrev, V. P. (2015). Analiz associacij polimorfnykh variantov genov modifikacii arterial'nogo davleniya i genov regulyacii immunnogo otveta s ishemicheskoj bolezn'yu serdca [Analysis of associations of polymorphic gene variants of blood pressure modification and immune response regulatory genes with ischemic heart disease]. Molekulyarnaya medicina, 4, 47-54. [in Russian].

[9] Martynovich, T. V., Akimova, N. S., Fedotov, E. A., \& Schwarz, Yu. G. (2014). Analiz geneticheskikh faktorov u bol'nykh khronicheskoj serdechnoj nedostatochnost'yu [Analysis of genetic factors in patients with chronic heart failure]. Mizhnarodnyi medychnyi zhurnal, 20(1), 21-29. [in Russian].

[10] Pavlova, O. S., Ogurtsova, S. E., Gorbat, T. V., Liventseva, M. M., Afonin, V. Yu., Malugin, V. I., \& Mrochek, A. G. (2016). Poligennye associacii polimorfizma genov renin-angiotenzin-al'dosteronovoj sistemy pri e'ssencial'noj arterial'noj gipertenzii [Polygenic association of the renin-angiotensin-aldosterone system polymorphisms in essential arterial hypertension]. Arterial'naya gipertenziya, 22(3), 253-262. [in Russian].

[11] Pishak, V. P., \& Riznichuk, M. O. (2013). Uchast polimorfnykh heniv u fenotypovykh proiavakh spadkovoi patolohii nyrok [Participation of polymorphic genes in the phenotypic manifestations of hereditary renal disease]. Dosiahnennia biolohii ta medytsyny, 1(21), 67-72. [in Ukrainian].

[12] Chak, T. A., Pavlyushchik, O. O., Khapaliuk, A. V., Afonin, V. Yu. Teplouhova, Yu. S., Sorokina, V. N., \& Bilodid, I. K. (2014). Vliyanie gena angiotenzinprevrashchayushchego fermenta na razvitie nejrososudistykh oslozhnenij pri sakharnom diabete 2 tipa [Effect of angiotensin converting enzyme gene on the development of neurovascular complications in type 2 diabetes mellitus]. Medicinskie novosti, 6(249), 53-56. [in Russian].

[13] Ahmetov, I. I., \& Fedotovskaya, O. N. (2015). Current progress in sport genomics. Adv. Clin. Chem., 70, 247-314. doi: 10.1016/ bs.acc.2015.03.003.

[14] Ben-Zaken, S., Eliakim, A., Nemet, D., \& Meckel, Y. (2016). Genetic variability among power athletes: the stronger vs. the faster. J. Strenght. Cond. Res. doi: 10.1519/JSC.0000000000001356.

[15] Bouchard, C. (2015). Exercise genomics--a paradigm shift is needed a commentary. British journal of Sports Medicine, 49(23), 1492-6. doi: 10.1136/bjsports-2015-095294.

[16] Drozdovska, S. B., Dosenko, V. E., Ahmetov, I. I., \& llyin, V. N. (2013). The association of gene polymorphisms with athlete status in Ukrainians. Biology of sport, 30(3), 163-167. doi: 10.5604/20831862.1059168.

[17] Dhamrait, S., Maubaret, C., Pedersen-Bjergaard, U., Brull Peter Gohlke, D. J., Payne J. R., World, M., et al. (2016). Mitochondrial uncoupling proteins regulate angiotensin-converting enzyme expression: crosstalk between cellular and endocrine metabolic regulators suggested by RNA interference and genetic studies. Inside the Cell, 1(1), 70-81. doi: 10.1002/icl3.1019.

[18] Garatachea, N., \& Lucia, A. (2013). Genes and the ageing muscle: a review on genetic association studies. Age (Dordr), 35(1), 207-213. doi: 10.1007/s11357-011-9327-0.

[19] Guth, L. M., \& Roth, S. M. (2013). Genetic influence on athletic performance. Curr. Opin. Pediatr., 25(6), 653-658. doi: 10.1097/ MOP.0b013e3283659087.

[20] Haykowsky, M. J., \& Tomczak, C. R. (2014). LV hypertrophy in resistance or endurance trained athletes: the Morganroth hypothesis is obsolete, most of the time. Heart, 100(16), 1225-6. doi: 10.1136/ heartjnl-2014-306208. 
[21] Hu, D. C., Zhao, X. L., Shao, J. C., Wang, W., Qian J., Chen, A. H., et al. (2014). Interaction of six candidate genes in essential hypertension. Genet. Mol. Res., 13(4), 8385-8395. doi: 10.4238/2014.

[22] Lindholm, M., \& Rundqvist, H. (2016). Skeletal muscle hypoxia-inducible factor-1 and exercise. Ex. Physiol., 101(1), 28-32. doi: 10.1113/ EP085318.

[23] Lundby, C., \& Jacobs, R. (2016). Adaptations of skeletal muscle mitochondria to exercise training. Ex. Physiol., 101(1), 17-22. doi: 10.1113/ EP085319.

[24] Ma, F., Yang, Y., Li, X., Zhou, F., Gao, C., Li, M., \& Gao, L. (2013). The association of sport performance with ACE and ACTN3 genetic polymorphisms: a systematic review and meta-analysis. PLOS One, 8(1), e54685. doi: 10.1371/journal.pone.0054685.

[25] Trappe, S., Luden, N., Minchev, K., Raue, U., Jemiolo, B., \& Trappe, T. A. (2015). Skeletal muscle signature of a champion sprint runner. J. Appl. Physiol., 118(12), 1460-6. doi: 10.1152/japplphysiol.00037.2015.

[26] Pitsiladis, Y., Wang, G., Wolfarth, B., Scott, R., Fuku, N., Mikami, E., et al. (2013). Genomics of elite sporting performance: what little we know and necessary advances. Br. J. Sports Med., 47(9), 550-5. doi: 10.1136/bjsports-2013-092400.

[27] Webborn, N., Williams, A., McNamee, M., Bouchard, C., Pitsiladis, Y., Ahmetov, I., et al. (2015). Direct-to-consumer genetic testing for predicting sports performance and talent identification: consensus statement. Br. J. Sports med., 49(23), 1486-91. doi: 10.1136/ bjsports-2015-095343.

[28] Williams, A. G., Day, S. H., Lockey, S. J., Heffernan, S. M., \& Erskine R. M. (2014). Genomics as a practical tool in sport-have we reached the starting line? Cellular and molecular exercise physiology, 3(1), 25-38. doi: 10.7457/cmep.v3i1.e6.

[29] Żebrowska, A., Waśkiewicz, Z., Zając, A., Gąsior, Z., Galbo, H., \& Langfort, J. (2013). IGF-1 response to arm exercise with eccentric and concentric muscle contractions in resistance-trained athletes with left ventricular hypertrophy. Int. J. Sports Med., 34(2), 116-122. doi: 10.1055/s-0032-1321720.

\section{Information about author:}

Malakhova S. M., MD, PhD, Associate Professor, Department of Physical Rehabilitation, Sports Medicine, Physical Training and Health, Zaporizhzhia State Medical University, Ukraine.

\section{Відомості про автора:}

Малахова С. М., канд. меА. наук, Аоцент каф. фізичної реабілітації, спортивної меАицини, фізичного виховання і зАоров'я, Запорізький Аержавний меАичний університет, Україна.

\section{Сведения об авторе:}

Малахова С. Н., канА. меА. наук, Аоцент каф. физической реабилитации, спортивной меАицины, физического воспитания и зАоровья, Запорожский государственный медицинский университет, Украина.

Conflicts of Interest: author has no conflict of interest to declare. Конфмікт інтересів: віАсутній.

Надійшла Ао редакції / Received: 14.11.2017

Після Аоопрацювання / Revised: 17.11.2017

Прийнято Ао Аруку / Accepted: 20.11.2017 